\title{
Public Participation in Science: The Future and Value of Citizen Science in the Drinking Water Research
}

\author{
Stijn Brouwer ${ }^{1, *(1)}$, Paul W. J. J. van der Wielen ${ }^{1,2}$, Merijn Schriks ${ }^{1,3}$, Maarten Claassen ${ }^{4}$ and \\ Jos Frijns ${ }^{1}$ \\ 1 KWR Watercycle Research Institute, P.O. Box 1072, 3430 BB Nieuwegein, The Netherlands; \\ Paul.van.der.Wielen@kwrwater.nl (P.W.J.J.v.d.W.); Merijn.schriks@vitens.nl (M.S.); \\ Jos.Frijns@kwrwater.nl (J.F.) \\ 2 Laboratory of Microbiology, Wageningen University, 6700 HB Wageningen, The Netherlands \\ 3 Vitens, 8001 BE Zwolle, The Netherlands \\ 4 Waternet, 1096 AC Amsterdam, The Netherlands; Maarten.Claassen@waternet.nl \\ * Correspondence: Stijn.Brouwer@kwrwater.nl; Tel.: +31-30-606-9662
}

Received: 12 February 2018; Accepted: 7 March 2018; Published: 8 March 2018

\begin{abstract}
This paper explores the value of involving citizens in the generation of knowledge in drinking water research. To this end, the significance of the 'Freshness of Water' citizen science project on the microbiological stability of drinking water was analyzed, supplemented with a series of expert interviews. In this project, citizens of Amsterdam participated in taking samples from their own kitchen tap and testing the water using test strips. The subsequent monitoring of bacteria revealed that the total number of bacterial species in all of the Amsterdam drinking water samples was high. For the participants, the presence of ten thousands of bacterial species in their drinking water, as well as the interpretation that this is perfectly normal and not a health concern, was obviously new. However, instead of causing concern or worry, this transparency clearly functioned as a strong confidence-inducing signal. A majority of the citizen scientists state that, as a result of their participation, their confidence in the quality of drinking water and the water company has increased. This study suggests that citizen science can raise the participant's water awareness and that, with the appropriate support, non-professionals can make a valuable contribution to scientific drinking water research.
\end{abstract}

Keywords: citizen science; drinking water quality; participation; knowledge generation; Amsterdam

\section{Introduction}

Even if the vital importance of drinking water provision has essentially been stable for the past few decades, the challenges water companies meet, the way they operate, and certainly the citizens they serve, have undergone significant changes [1,2]. One such change is that the water sector has become more technological and technocratic [3]. According to a recent water governance assessment in the Netherlands from the Organisation for Economic Co-operation and Development (OECD), a resulting "gap" or "distance" between water (companies) and citizens (customers) can be observed [4]. Indeed, and despite the country's unique history and connection with water [5], the OECD concludes that the citizens in the Netherlands are largely unaware of water related risks and (potential) threats to fresh water security. At the same time, and separate from the question whether this should be considered as a reaction to or merely a societal development in the opposite direction, a shift towards active citizenship can be witnessed [6,7].

Perhaps one of the most interesting and challenging manifestations of this more proactive citizenship-especially with regard to the present challenges and call for more combined and multidisciplinary solutions in the water domain $[8,9]$, is the role and significance of knowledge. 
Through fast evolving developments in the field of information and communication technology and the expanding impact of the internet and smartphones, nowadays, citizens are able to retrieve information on virtually every imaginable subject at any time of the day. In fact, citizens not only 'consume', but increasingly also 'produce' or require information, transparency, and open data; a development that not only results from, but also contributes to a growing self-awareness of citizens [10]. Evidently, this development brings challenges and obstacles in the field of transparency, and, for instance, risk communication [11]. At the same time, the democratization of knowledge and recent surge of new technologies also opens up opportunities in the field of public participation in the form of co-creating knowledge and innovation [12]. Over the past decade a "new dawn" of citizen science can be witnessed [13-17]. Although public participation in science has existed for centuries, in the past few years citizen science projects have grown spectacularly in number, scale and scope $[13,18-20]$.

In simple words, citizen science refers to the participation of the general public, i.e., non-scientists, in the generation of scientific knowledge [21]. Citizen science as a concept was developed from two origins, one in the social sciences and one in the natural sciences [22]. Bonney [23] coined the concept to refer to projects involving data gathered by citizens, whereas, independently, Irwin [24] defined citizen science in the realm of philosophy of science, describing the concept as an "arena where different knowledge claims can meet and cross-fertilize" [25]. Grounded in the work of, among others, Bonney et al. [26], Shirk et al. [13], and Buytaert et al. [21], in this study we define citizen science as any form of active public participation in the process of research to generate science-based knowledge, from setting the research agenda by asking research questions, to collecting data, and/or analyzing the results.

Appealing examples of citizen science studies include the Galaxy Zoo project, which received more than 50 million galaxy classifications during its first year by more than 150,000 people [15] and the eBird project which monthly receives 25 million observations of bird presences across the United States (U.S) [14]. Other domains with a large number of citizen science projects include social and space sciences [27], climate science and, rather prominently, ecology and conservation science $[16,18,19]$, as well as many others. Reinforced by technological developments, including the rise of robust, cheap, and low-maintenance sensors, also in the complex arena of water resource management, citizen science is unmistakably upcoming $[21,28,29]$.

Using the measurement of chemical parameters and biological indicators, citizen science in the water sector is most prominent in the field of surface water quality monitoring programs $[17,30]$. Water quality monitoring by citizen scientists is especially well-established in the United States; the 2017 EPA's National Directory of Volunteer Monitoring Programs [31] lists more than a thousand programs operating within the U.S. alone. In addition to citizen science volunteers that engage in surface water quality monitoring programs, there are several examples of community-based approaches to groundwater monitoring, being mostly focused on water sampling and chemical analysis [32], as well as citizen science projects related to the monitoring of groundwater levels [33] and flood risk management [34].

Despite the fact that the involvement of citizen-scientists is widely practiced and proves highly successful for numerous tasks and in many domains, the involvement of non-scientists in the field of drinking water is rather scarce, and is often limited to the collection of data in the form of water samples, basic hydro-chemical parameters, turbidity, conductivity/salinity, pressure, hardness, redox potential, and $\mathrm{pH}[21,35]$. To our knowledge, before the start of our citizen science project 'The Freshness of Water', which is elaborated on in Section 2, a citizen science project on drinking water in the Netherlands has never been conducted. The objective of this paper is to provide more insight on the future opportunities and potential of citizen science in the realm of drinking water, and in particular, to shed greater light on the value of involving citizens in the generation of knowledge in this field. To this end, the paper analyses the value and significance of the 'Freshness of Water' citizen science project, and explores the developments and drivers for citizen science in the Dutch drinking water sector. 
The remainder of this paper is organized into four sections. Section 2 expands on the research design of this study, encompassing the development and implementation of the citizen science project, including an evaluation survey and focus group, as well as a set of 15 expert interviews. This study's findings on the value, effects and potential based on the citizen science project are presented in Section 3. In Section 4, we elaborate on the developments and drivers related to the rise of citizen science in the realm of the drinking water domain. Concluding remarks on the value and the potential of citizen science in the drinking water sector are given in Section 5.

\section{Materials and Methods}

The empirical research of our paper is based on the first hand experiences of setting up and running an innovative citizen science project on the microbiological stability of drinking water (i.e., the effect of transportation on freshness of water at the tap), as well as a series of in-depth expert interviews. The environment informing this study is the drinking water system in the city of Amsterdam.

\subsection{Citizen Science Project}

As mentioned, the principal source of data in this study is formed by the 'Freshness of Water' citizen science project on the microbiological stability of drinking water. This multi-purpose project can be characterized as primary a contributory citizen science project, in which members of the public merely collect data for scientists to use in their research [26]. For the citizen scientists, participation in the project provided the opportunity to actively contribute to innovative scientific research, to connect to a team of scientists, drinking water professionals and co-volunteers, as well as to learn about drinking water, microbes, and more generally, scientific research methodologies. For the involved drinking water company (Waternet, the water cycle company for Amsterdam), participation in this citizen science project provided the opportunity to engage with their customers in an innovative manner, and to obtain experience with customers that sample, and investigate their drinking water in a small and relatively controlled setting. Finally, from the researchers' point of view, the involvement of volunteers not only enabled the collection of a large set of water samples after a night stagnation, a type of sample that for regular samplers is otherwise impossible or very difficult to collect, but first and foremost provided the opportunity to get a better understanding of the value and significance of citizen science in the drinking water sector, including exploring the question to what extent non-professionals are capable of sampling accurately and generating acceptable data. From a social science perspective, the aim of the project was twofold; first, to analyze the value and potential of citizen science in the drinking water sector; and, second, to evaluate the experiences and meaning of involving citizens in this domain. From a natural sciences perspective, the project aimed to acquire a better understanding of how the bacterial community composition in drinking water changes during transportation in the distribution system, after stagnation in the premises plumbing system, and by using the highly innovative 'Next Generation Sequencing' technology, to learn about so-far unclassified bacteria in the drinking water of Amsterdam. Except for some general analysis, the results on the bacterial composition of drinking water are reported in a separate paper (forthcoming).

To answer this project's social science questions, three different online surveys with the citizen scientists involved were used, starting with an online registration survey $(n=85)$, followed by a data sharing $(100 \%$ response rate) and evaluation survey (79\% response rate). In addition, a qualitative focus group with some of the involved citizen scientists $(n=9)$ was conducted towards the end of the project. The unique property of focus groups is the interaction found in a group, whereby participants not only respond to the researcher's questions, but also react to and on each other [36]. The objective of including a focus group was to collect qualitative information on the experience and value of participating citizen scientists. Moreover, the focus group results assisted to improve the design of the evaluation survey. 


\subsection{Expert Interviews}

Next, to the citizen science project, a second source of data was formed by 15 semi-structured interviews with citizen science experts, in two rounds (1st round, $n=6$, 2nd round, $n=9$ ). The interviewees in the first round were selected on the basis of their knowledge of participation in the Netherlands water sector, citizen science, and/or new modes of knowledge production, and included academic researchers, water sector professionals, and a municipal citizen science initiator. The objective of the first round of interviews was to elicit expert knowledge regarding the value, meaning and potential of citizen science, particularly within the domain of drinking water in the Netherlands. All of the first round interviews were face-to-face interviews, lasted one hour on average, and took place in the summer of 2015. Given the diversity of expertise among the experts, a tailored interview guide for each respondent was developed prior to each interview. In the second interview round, taking place in the autumn of 2016, interviews were conducted with both (international) leading academics and non-governmental organization (NGO) professionals working with citizen science. The aim of these interviews was to identify relevant citizen science trends and practices, as well as to explore the opportunities and threats for drinking water companies towards 2025. Because of the dispersed locations of the experts, and in view of the limited time available, all second-round interviews were conducted by telephone, each call lasting on average one hour. In this round, data were collected using a semi-structured interview format with a standard set of questions for all of the participants. Follow-up questions varied between the interviewees, depending on the individual narratives. Both the focus group discussion and all interviews were recorded, transcribed or summarized, and then analyzed to identify patterns and themes that emerged from the data, using the general qualitative phases identified by Baptiste [37]: (i) defining the analysis; (ii) classifying the data; (iii) making connections between data; and, (iv) conveying the message(s).

\section{The 'Freshness of Water'}

The multidisciplinary citizen science 'Freshness of Water' project, which was inspired by the Water Microbiome Project in Pittsburgh [38], took place between April and October 2016. This section provides a step-by-step description of the process, together with an interpretation of the data.

\subsection{Recruitment and Selection}

Enthusiastic participants willing to volunteer are the backbone of each and every citizen science project. In our project, we recruited participants exclusively via Facebook by publicizing a link to a project registration page and online registration survey, administered via SurveyMonkey. Within a timespan of one month, 125 citizens registered, 85 of them fully completed their registration, which was far more than the maximum of 50 volunteers we were looking for. As depicted in Figure 1, most respondents were younger than $45(66 \%)$; the age group with the most respondents was $25-34(32 \%)$. Thirteen respondents were 24 or younger, three respondents were over age $65(4 \%)$. About two-third of the respondents were female (66\%) and the rest were male $(34 \%)$. These results are divergent from previous studies, including by Raddick et al. [15] that collected survey responses from almost 11,000 volunteers of the before-mentioned Galaxy Zoo project, citing a common excess of male volunteers between the ages of 50 and 65. A plausible explanation for the relative many young volunteers in our study is the recruitment procedure via Facebook. We have, however, no valid explanation for the overrepresentation of female registrations. 


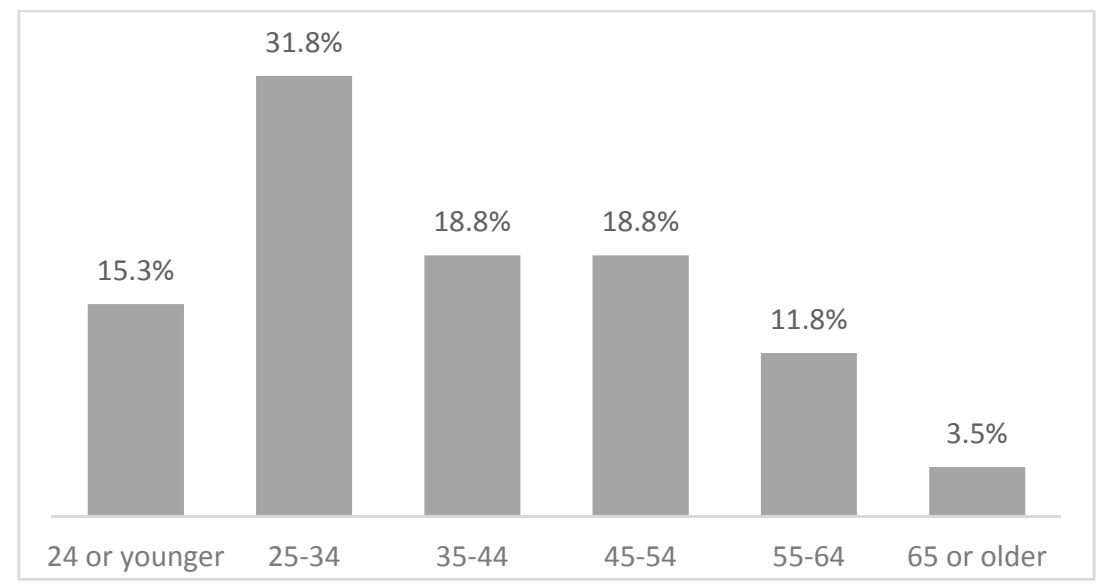

Figure 1. Age distribution respondents.

The majority of the respondents were well educated: $30 \%$ with a bachelor's degree and $47 \%$ with a graduate degree as highest completed education. Also, here we find diversity; ten respondents $(12 \%)$ had a lower secondary professional education or intermediate vocational education as highest completed educational level. A large portion of respondents had not previously participated in a scientific study $(62 \%)$. In view of the study's goal to better understand the effect of transportation and storage on the freshness of water, also an equal distribution over the city of Amsterdam was important. Although the majority of registered participants lived downtown, this study, as shown in Figure 2, recruited participants from all over the city.

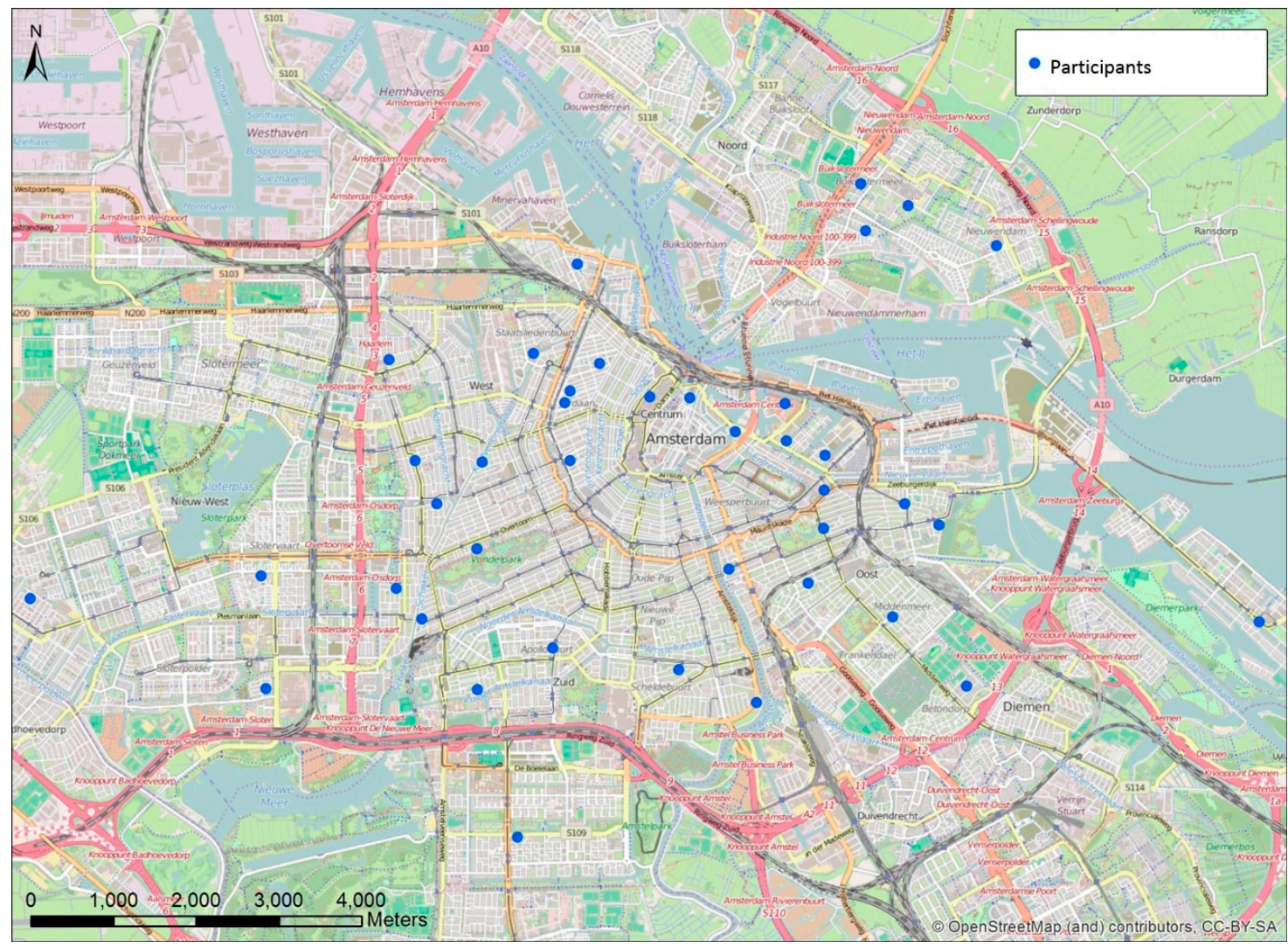

Figure 2. Participating citizen scientists at postal code level, Amsterdam. 
City distribution was the first criterion to select the 50 participants for the project from the 85 registered volunteers. The second criterion was demographic variety, whereby account was taken of the male/female ratio, age distribution, and educational background. After this selection procedure, all of the selected participants were contacted via e-mail to join a dedicated (private) Facebook project group and to confirm their presence at the kick-off meeting. This last step ultimately led to 43 confirmed participants.

An important question that relates to the desired structure of citizen science projects is why participants choose to volunteer and devote their time and energy to, in this case, research into the 'freshness' of their own drinking water. Knowledge on the motivations of participants is important as, obviously, having motivated participants is essential for the project's success [39]. Although there is much literature on motivations for volunteering $[15,28,40]$, questions about what motivates citizens to volunteer in science projects, let alone citizen science projects in the water domain, remain subject for further research [41,42]. Therefore, and in addition to housing and demographic characteristics, the online registration survey assessed participants' views regarding several motivational factors based on Raddick et al. [15] and Jennet et al. [39]. Respondents were asked to rank the three most important motivations to participate among the following seven options: (i) special interest in drinking water; (ii) special interest in microbes; (iii) acquiring new knowledge; (iv) contributing to innovative scientific research; (v) fun/interest to carry out tests/measurements at home; (vi) being part of a team; and, (vii) other (see Table 1).

Table 1. The 1st, 2nd, and 3rd most important motivation for volunteers to participate in the 'Freshness of Water' citizen science project.

\begin{tabular}{cccc}
\hline & 1st & 2nd & 3rd \\
\hline Contributing to innovative scientific research & $35 \%$ & $22 \%$ & $14 \%$ \\
Special interest in drinking water & $26 \%$ & $19 \%$ & $13 \%$ \\
Fun/interest to carry out tests/measurements at home & $21 \%$ & $21 \%$ & $25 \%$ \\
Acquiring new knowledge & $8 \%$ & $21 \%$ & $32 \%$ \\
Special interest in microbes & $8 \%$ & $14 \%$ & $11 \%$ \\
Other & $1 \%$ & $1 \%$ & $1 \%$ \\
Being part of a team & $0 \%$ & $1 \%$ & $5 \%$ \\
\hline
\end{tabular}

The highest percentage of respondents ranked "contributing to innovative scientific research" as the most important motivation for their participation (35\%). A smaller percentage of participants ranked "a special interests in drinking water" (26\%) and "fun/interest to carry out tests/measurements at home" $(21 \%)$ as the most important motivation to register as citizen science volunteer. These results support Haywood's [40] claim that more than just the collection of data and contributing to research is important to the participants, and are strikingly similar to earlier studies, including Raddick et al. [15] and Alender [41], with "contributing to original scientific research" as the strongest motivator. Apart from "other", "being part of a team" was the weakest motivator in the present study. Also, this finding is consistent with data presented by Raddick et al. [15].

\subsection{From Volunteers to Citizen Scientists}

After the recruitment and selection phase, a kick-off meeting was organized, which gathered selected volunteers, KWR Watercycle Research Institute scientists, and Waternet professionals. Besides several content related presentations, the intention of the meeting was to get acquainted with each other, as well as handing out a water test kit. The latter contained test strips (Sani-Check BF dipsticks; Biosan Laboratories, Warren, MI, USA), three plastic sample bottles, a pair of gloves, labels, instructions for analyzing the microbes, and a protocol for sampling. The protocol was designed to be reliable, yet easy to follow, and included step-by-step instructions outlining (i) how to take the drinking water samples, (ii) how to collect an additional water sample of their own choice, and (iii) how to use 
and read the test strips. Participants were also provided with an instructional video (in Dutch) that portrayed the details of the procedure for collecting the water samples.

In the weeks following the kick-off meeting, all of the citizen scientists took two drinking water samples from their own kitchen tap. One sample was taken early in the morning before consumption so that it represents drinking water that had remained overnight in the premises plumbing system of the building. The other sample was taken after five minutes of running water so that it represents drinking water from the distribution system. In addition, all citizen scientists could contribute to the study by adding one additional water sample of their own choice. Mostly this opportunity was used to test microbes in drinking water that was contained for two to five days in bottles, drinking glasses, electric kettles, or coffeemakers. After a maximum storage at fridge temperature for one day, all of the samples were collected by a courier service and transported to the laboratory of KWR Watercycle Research Institute, where the adenosine triphosphate (ATP) concentration, total cell numbers, and bacterial community composition were analyzed. In addition to this laboratory analysis, citizen scientists carried out two tap water analyses using two different test strips (one to count cultivable bacteria and the other to count cultivable fungi) at home. Test strips were inoculated with the water sample and subsequently incubated at room temperature for seven days. After three, five, and seven days, the citizen scientists were asked to count the number of 'dots' i.e., microbe colonies on the strips. After these seven days, along with personal data and a question on how they experienced this home analysis, citizen scientists entered the test strip results in an online survey using SurveyMonkey software.

Without exception, all the citizen scientists collected the drinking water samples, carried out their home tests and shared the results. A plausible explanation for this $100 \%$ response may relate to the intensive contact between the project team and the citizen scientists in combination with a relative long registration process, which might have functioned as a gatekeeper mechanism (indeed, $32 \%$ of the registrations were not fully completed). At least as important, the laboratory analyses showed that water sampling had been carried out carefully by all citizen scientists; data from none of the water samples had to be excluded due to inaccurate sampling or showing a deviating value for the microbiological parameters. This result is coherent with earlier studies that have validated that citizen science in the domain of drinking water can generate acceptable data [35].

\subsection{Openness and Transparency}

Besides an open interaction with the citizen scientists, a key element of the project consisted of the transparent feedback of results. After the kick-off meeting, this interaction mainly took place on the dedicated Facebook-page linking to an interactive GIS map, allowing for users to learn about the results of their own collected samples, as well as about all other data points in the city. A layman interpretation of the data was shared via a memo and at a public meeting. A preceding invitation to the citizen scientists to share their own interpretation of the data did not yield many responses. Although it is beyond the scope of this paper to present a complete analysis of the bacterial composition of drinking water, it is useful for our discussion to provide some basic results on the microbial biomass, the bacterial numbers, and the bacterial community composition (obtained with next generation sequencing of the bacterial 16S ribosomal RNA gene) that were found in the different samples. This basic analysis is helpful for understanding the significance of the perception and evaluation of the citizen scientists in later discussions.

The results of the test strips used by the citizen scientists at home showed that drinking water that was taken directly from the tap contained virtually no cultivable bacteria or fungi, whereas drinking water that had been stored in a bottle, glass, or water bottle contained many cultivable bacteria and fungi, i.e., bacterial growth occurred during the storage of water. The total microbial biomass was determined by measuring the concentration of ATP, an energy rich compound that is present in all living organisms. The ATP concentration in drinking water samples taken after a five-minute flow was low (averagely $1.6 \mathrm{ng} / \mathrm{L}$ ATP). This parameter increased slightly, yet significantly, when the drinking water had resided overnight in the home's premises plumbing system (averagely $2.4 \mathrm{ng} / \mathrm{L}$ 
ATP). All of the ATP-concentrations measured in this study were below $6 \mathrm{ng} / \mathrm{L}$ ATP, whereas in the Netherlands only drinking water having concentrations above $10 \mathrm{ng}$ ATP/L are considered high [43,44]. Membrane-intact and membrane-compromised cells (as a measure for live and dead cells, respectively) were determined using flow cytometry. Unlike the ATP concentration, the number of membrane-intact cells in drinking water directly sampled (averagely 83,000 cells $/ \mathrm{mL}$ ) did not significantly differ from water after a five-minute flow (averagely 69,000 cells $/ \mathrm{mL}$ ). With the aim to contextualize these data on the biomass concentration and cell counts, as well as to stress the fact that this study reconfirmed that drinking water is a fresh product, additional data were provided for among others, treated waste water, and canal and lake surface water.

The results from the next generation sequencing analyses, making it possible to classify millions of bacteria at the DNA level, show that the total number of bacteria species in all of the Amsterdam drinking water samples was higher than 22,000, which is more than has been observed in drinking water of other countries [45-47]. Although follow-up research should give a definitive answer, we expect that this high diversity of species can be explained by the fact that in the Netherlands, in contrast to most other countries, drinking water is not distributed with a disinfectant residual [48]. Not surprisingly, but of course new for the citizen scientists, was the finding that the drinking water sampled (immediately or following a five-minute flow) contained bacteria that for an important proportion (30-50\%) are still unidentified. Although the characteristics and properties of these bacteria are still to be discovered, and this is also communicated with the citizen scientists, it is not to be expected that these unknown bacteria are causing health problems.

Although, as mentioned, the citizen scientists involved in this study did not so much share their own interpretation of the data, one of them discovered that the ATP concentration in his drinking water samples showed outlier values. This observation was followed up by additional measurements conducted by Waternet professionals. Eventually, and despite the fact that these outlier values were primarily caused by a privately installed ion exchanger to home-treat the drinking water, the involved drinking water company even flushed out some drinking water pipes near this particular address. By doing so, they fulfilled their promise of considering potential outliers not as a threat but as an opportunity to learn and improve.

\subsection{Evaluation and Perception}

Based on the evaluation survey and focus group findings, this study concludes that a majority of the citizen scientists felt that their participation was both fun ( $88 \%)$ and educational $(94 \%)$. Participants specifically valued the home test strip analysis. One of them, for instance, stated: "What I liked most about the project was the use of the two home test strips ( ... ), the analysis of my own tap water, and to check every day whether more dots [microbes] had grown". Also, the interactions between and among citizen and professional scientists during the two physical meetings and the Facebook-group are important elements of the positive evaluation. Participants not only enjoyed and valued the project, most of them $(79 \%)$ also perceive their individual contribution to the study as valuable or important. This is an important result, as previous studies indicate that being "undervalued" by the professional scientists may be highly detrimental [21].

More than one-third (38\%) of the citizen scientists indicated that they would have liked to be involved more in the study. While a small number of them indicated that they would have liked to be involved in the design or analysis phase of the study, follow-up questions on this topic suggest that this finding mostly relates to the desire to add more drinking water samples of their own choice to the study. In fact, this element of the project is viewed by $82 \%$ of the participants view as an important added value. The wish to add more samples to the study was, for instance, expressed by a citizen scientist who claimed: "If the test-strips would cost $€ 0.50$, I would have liked to have a whole box of them". Not only did participants express the wish to add additional samples of water contained in different ways and over longer periods of time, they also expressed enthusiasm to analyze more direct tap drinking water samples, for instance sampled from different taps around the house, in different 
seasons, and/or after long periods of absence such as holidays. Whether this calls for a larger role for all participants, however, is another matter, not in the least because previous studies suggest that excessive expectations on participants can demotivate and work counterproductive [49].

The combined survey and focus group data furthermore suggest positive effects on water awareness, perceptions and knowledge of participating citizen scientists. Indeed, as shown in Figure 3, a large majority (91\%) of them states that their awareness of aspects related to drinking water quality has increased. One citizen scientist described: "I learned a lot of facts and figures and my awareness increased. Of course, I did know it is special that we always have access to clean drinking water. But what it really takes to produce and transport such water? No".

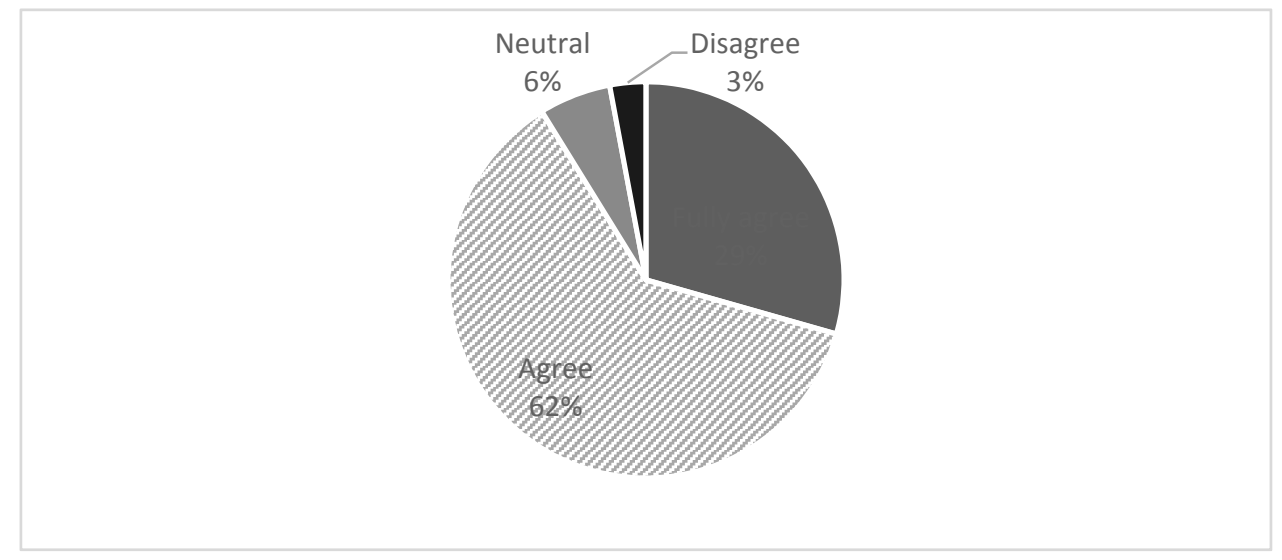

Figure 3. Impact on awareness (answers to the statement 'As a result of participation, my awareness has increased').

About one third (29\%) of them has, as a direct result of their participation, searched for additional information on drinking water, and about half $(47 \%)$ the participants states that their view on drinking water has changed. One citizen scientist explained: "After participating I am more conscious of what it takes to get water from the tap ( ... ) I now have a clearer picture of, and as a result more respect for, all the effort they [the drinking water company] put in that process". Furthermore, and despite the fact that participants learned about the presence of ten thousands of alive cells and bacterial species in their drinking water, a clear majority of the participants agree, as shown in Figure 4 respectively $65 \%$ and $59 \%$, that as a result of their participation, their confidence in the quality of drinking water and the water company has increased.

Also the focus group indicates that confidence in both the quality of drinking water and the drinking water company has increased; citizen scientists from the focus group indicated that transparency, including information and a dialog about complicated issues such as microbes, is a strong, confidence-inducing signal. In this regard, comments were made such as: "I have more confidence in a company that is open, transparent and allows (third party) analysis. I rather trust a company that is opening up than trust a company that secludes oneself and doesn't share". About one third (35\%) of the participants indicated that their participation in the project led them to modify their drinking water behavior, including the implementation of water saving practices as a result of a grown awareness, and replacing or running water more often as a direct result of the analysis on microbes. One citizen scientist explained: "I don't think my drinking water behavior has changed, that is, when we talk about water directly from the tap. It's a different story when we talk about water contained in bottles. Previously, when thirsty I would grab any bottle of water in my hot car, even weeks old with a weird taste. Now I would think twice in such situation". Increased awareness and the possibility of behavioral change after participating in citizen science projects have been earlier reported by, for instance, Johnson et al. [42] and Thornhill et al. [17]. 


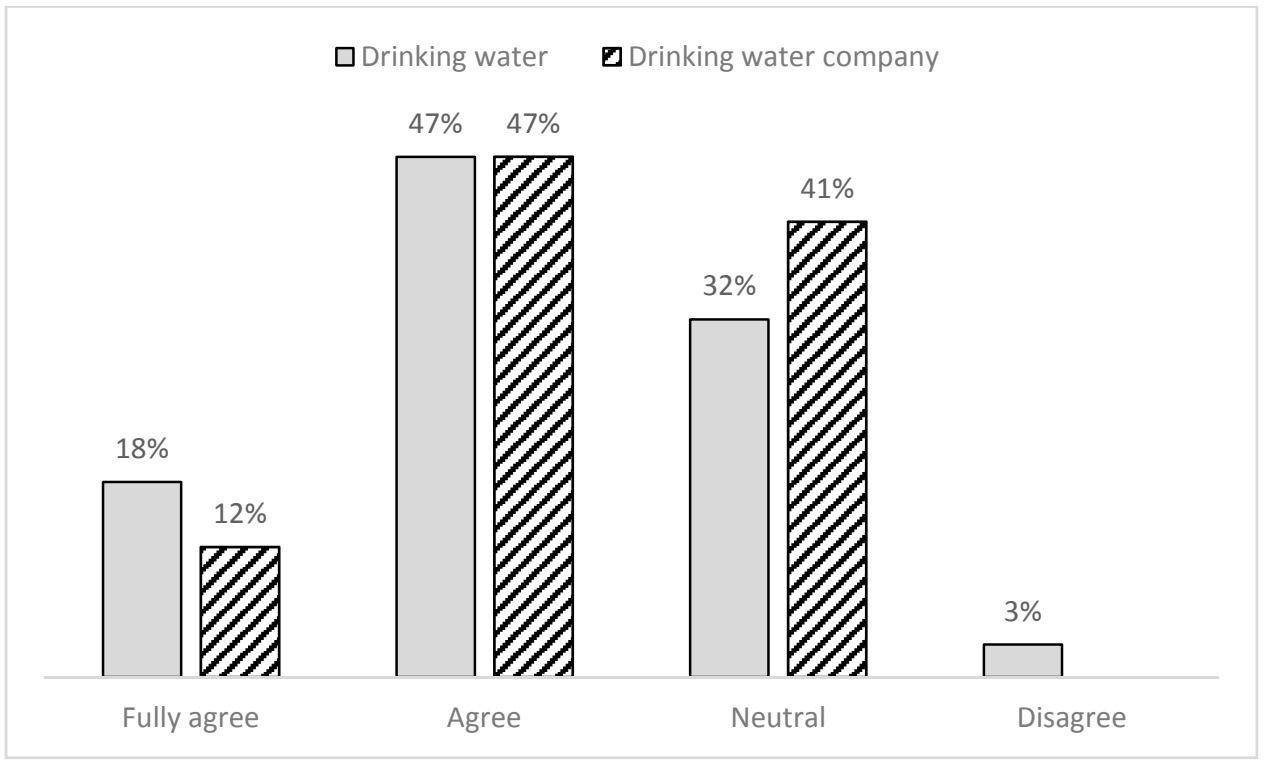

Figure 4. Impact on confidence (answer to the statement 'As a result of my participation, the level of confidence in drinking water quality/the drinking water company has increased').

In conclusion, the citizen science project clearly suggests that as a result of their participation, citizens feel closer connected to both their drinking water and their drinking water provider. Virtually all of the citizen scientists involved (97\%) indicated that they would certainly consider participating in another citizen science project related to drinking water in the future. Two-thirds of them $(67 \%)$ also indicated that they were open to be involved in other ways related to drinking water. For instance, one citizen scientist commented: "Suppose Waternet would like to start a new campaign to explain how it [the supply of drinking water] works (...) I think many of us would be willing to help them".

\section{Opportunities, Drivers and Challenges}

In order to further elucidate the value and significance of our project and to acquire a better understanding of the potential of citizen science in the drinking water domain, a second source of data was formed by 15 semi-structured interviews with experts in the field. To capture different perspectives, we interviewed citizen science experts from a variety of backgrounds, professions, both within the Netherlands and internationally. Despite their diversity, the experts were unanimous in their view that citizen science is everything but a temporary phenomenon. The biggest growth of citizen science is expected in the fields of environmental monitoring and health. If only because water connects to both these domains, experts foresee a growth of (drinking) water citizen science projects in number, scale, and scope. One interviewee summarized his line of reasoning in this manner: "The link between drinking water companies, scientists and citizen science is pretty linear. You would imagine it's a match made in heaven. Water companies and scientists need information, whereas many citizens are ready to provide that sort of information as it is also in their best interest that water is managed properly".

Furthermore, and coinciding with the results of the 'Freshness of Water' project, several interviewed experts flagged the idea that citizen science has the potential to raise public awareness. Others, primarily stress the call for authentic relationships, and the idea that water companies and institutions investing in sustainable relationships with their customers may be more successful in the long run. In short, based on the interview data, we are led to the conclusion that the active involvement of non-professionals in water research is something to be reckoned with for a long time to come.

According to the interviewed experts, the growing importance of citizen science in the water sector can be attributed to three main developments. The first development pushing for a growth of citizen science projects is the fast technological progress, including the rapid development and the 
decreasing costs of advanced sensors and easy-to-use computer and telephone applications. One of the experts, for instance, mentioned: "Better and cheaper technology will become available for ever more people". ICT developments already have boosted the use of data and disclosure of information in water governance [50], and it is expected that citizen science will further support this development.

In addition to this technological push, all of the experts refer to the societal developments of participation, social awareness, and empowerment that facilitate citizen science. According to various experts, in view of the current knowledge and educational level of citizens in the Netherlands, a growing group of people simply cannot be stopped to inquire. Especially, when topics directly relate to people's daily lives, experts expect an intensified involvement of citizens, including more autonomous or so-called bottom-up citizen science initiatives. Some experts even argue that without the involvement of citizens, future interventions in public space may become unattainable. In this regard, several of the interviewed experts speak about 'smart citizens', articulated and well educated members of society, perfectly able to find the means to reach their goals, citizen science being one such mean.

The third main development that is stressed by the experts contributing to a growth in citizen science is the so-called "legitimacy crisis" of science [19,32]. In view of this crisis, and the overall erosion of authority and expert knowledge, ever more people question why their knowledge would be inferior to that of "the expert". Citizen science, in their opinion, can function as a remedy to this crisis. Coinciding with various studies, including Bonney et al. [51] and Johnson et al. [42], the experts involved in this study witness an overall increasing acceptance of citizen science within the scientific community. They distinguish between scholars that regard the volunteering efforts of citizens primarily as a cheap labor, scholars that first and foremost appreciate the involvement of citizens as new sources of knowledge, and scholars that primarily stress the intrinsic value of citizen science. This growing support from the academic community accords with, among others, the fact that idea of Responsible Research and Innovation (RRI) is defined as a 'cross-cutting issue' in the EU Research and Innovation funding programme Horizon 2020 [52,53], as well as research funders, such as the National Science Foundation in the USA and the Natural Environment Research Council in the UK, which now impose upon every grantholder to undertake project-related science outreach activities [54]. Along these, what could be regarded as positive drivers, the involvement of non-professionals in drinking water research may also prompted by the desire to prevent unwanted developments. In this regard, one expert for instance remarked: "If science does not adequately respond to the concerns and questions of society, citizens may switch to bottled water, ( . . ) or look for pseudo scientists who do provide answers, including providers of all kinds of equipment to supposedly purify your water".

According to the experts in our study, wrongful interpretation of data and unnecessary concerns are the most important challenges or risk associated with citizen science in the drinking water domain. Also, in the preparatory stages of the 'Freshness of Water' project, this was a huge hurdle to overcome. Indeed, given the positive results of our study, one could retrospectively consider the participation of the involved drinking water company as a matter of course. Yet, nothing is further from the truth; involving citizens in research and providing transparency about the complicated, and possibly alarming, subject of microbes in drinking water, which strongly deviates from their regular communication messages, initially raised many concerns and opposition. It ultimately was the recognition of the opportunity to engage with customers in an innovative manner and the change to obtain experience with citizen science in a small and controlled setting that decided the drinking water company to participate. Indeed, the very nature of citizen science is that such monitoring of tap water could be organized by any citizen and/or university or NGO without the involvement of the water company, and thus it is the interest of the water company to participate and learn from this project. According to our interviewed experts, the fear for wrongful interpretation of data and unnecessary concerns should never be reason to reject or attenuate the potential of citizen science. Or, as one of the experts put it: "Instead of thinking about the possible opportunities and threats citizen science may present, it is more useful to realize the trend and to think about quality care". As explained above, 
and surely related to the support and careful explanation of the data, the Freshness of Water project increased levels of confidence instead of fear.

The call for citizen science projects encompassing education and training and quality control is echoed by many of the interviewed experts, as is the idea that this is not always easy to incorporate these elements in practice. Among others, in the light of the often heard wish of citizen scientists to receive rapid feedback, this pledge may cause a trade-off between feedback time and quality control. Another growing challenge relates to giving consequence to citizen science outcomes. At present, according to several interviewed experts, institutions too often embrace citizen science with a largely noncommittal attitude. In the long run such an attitude may be in insufficient, or as one expert put it: "People may find it unsatisfactory to merely collect data when not linked to, for instance, policy or the design of their own neighborhood". In our project, a first step in this direction was made by Waternet who, as explained above, conducted additional measurements and eventually flushed out some drinking water pipes after one of the involved citizen scientists flagged out certain atypical results at his address.

Other challenges put forward by the experts in our study relate to the long term commitment of volunteers, the need for localization and tailor-made projects, data integration between different citizen science project, social inclusivity and accessibility, as well as the recognition of diversity among the volunteers. One respondent mentioned in this regard: "One of the biggest citizen science challenges is to open up to a wider group of participants. When citizen science projects do not become more inclusive, it will not succeed its potential to connect science with the entire society". Finally, several experts warn for a too narrow interpretation of citizen science wherein volunteers are merely viewed as cheap labor and the emancipatory side of it is pushed aside. In addition, they warn for the risks that are associated with citizen science projects that are initiated as a marketing-tool. Although this particular risk of citizen science was not part of our study, based on the feedback that we received during the project in which citizens underlined the importance of the innovative and scientific character of the study, we certainly recognize these challenges.

\section{Discussion}

The findings of this study have provided a more meaningful understanding on the societal significance, value, and potential of citizen science in the drinking water domain. The systematic analysis of the 'Freshness of Water' project shows that citizen scientists were found to be reliable in sampling and measuring suggesting that, with the appropriate support, non-professionals can make a valuable contribution to scientific drinking water research. Furthermore, this study suggests that citizen science can raise the participant's knowledge and act as a catalyst for increased water awareness, and therefore has the potential of contributing to bridging the public-water awareness gap, as defined by the OECD [4]. In addition, and despite the fact that participants learned about the presence of ten thousands of cells and bacterial species in their drinking water, this study indicates that confidence in both the quality of drinking water and the water company can increase as a result of participation. In this study, transparency, including data about complicated issues, such as microbes, clearly functioned as a strong, confidence-inducing signal.

Based on these promising findings, alongside the expert interviews on the developments and drivers for citizen science in the drinking water sector, we are led to the conclusion that citizen science will become more distributed and widely practiced in this realm. In fact, after the 'Freshness of Water' project, the potential of citizen science is not only recognized by the Amsterdam water company; several other drinking water companies in the Netherlands have now started or announced new citizen science projects. In addition to generating relevant research data and increasing scientific literacy, our research suggests that citizen science has the potential to provide benefits beyond science. It represents a promising option for collecting and communicating scientific knowledge that more people can access, understand, and trust. 
At the same time, we acknowledge that citizen science is not a panacea and should never been pursued as an aim in itself. Furthermore, we recognize that many citizen science challenges remain, including inclusivity, accessibility, and the risk of wrongful interpretation of data. In view of this, we strongly encourage new citizen science studies in the drinking water domain, varying in scope, scale, and approach, along with strengthening its theoretical grounding. Finally, future research is needed to further elucidate how citizen science can deliver positive and meaningful outcomes in the long run. We think that new citizen science projects in the drinking water sector, preferably in conjunction with empirical work carried out in other domains, can strengthen both the theory of citizens science, as well as the practical relevance of this promising development in knowledge creation.

Acknowledgments: The authors would like to thank the citizen scientists that participated in the project study. We would also like to thank all interviewees for sharing their ideas on the value and future of citizen science in the drinking water sector, Kyle Bibby (University of Pittsburgh), the KWR-Waternet project team, and the staff of the microbiological laboratory of KWR Watercycle Research Institute for analyzing the samples. A major part of the outcomes presented in this paper was based on research financed by the Joint Research Programme of the drinking water companies in The Netherlands.

Author Contributions: Stijn Brouwer conceived and designed the research methodology, collected and analyzed the social science data, and led the writing of the paper; Paul W.J.J. van der Wielen conceived and designed the research methodology, collected and analyzed the natural science data and contributed to writing the paper; Merijn Schriks, Maarten Claassen and Jos Frijns conceived and designed the research methodology and contributed to writing the paper.

Conflicts of Interest: The authors declare no conflict of interest. The founding sponsors had no role in the design of the study; in the collection, analyses, or interpretation of data; in the writing of the manuscript, and in the decision to publish the results.

\section{References}

1. Hegger, D.L.T.; Spaargaren, G.; van Vliet, B.J.M.; Frijns, J. Consumer-inclusive innovation strategies for the dutch water supply sector: Opportunities for more sustainable products and services. NJAS Wagening. J. Life Sci. 2011, 58, 49-56. [CrossRef]

2. Van Vliet, B.J. Sustainable innovation in network-bound systems: Implications for the consumption of water, waste water and electricity services. J. Environ. Policy Plan. 2012, 14, 263-278. [CrossRef]

3. Lintsen, H. Two centuries of central water management in the netherlands. Technol. Cult. 2002, 43, 549-568. [CrossRef]

4. Organisation for Economic Co-Operation and Development (OECD). Water Governance in the Netherlands: Fit for the Future; OECD: Paris, France, 2014.

5. Borger, G.; Ligtendag, W. The role of water in the development of the netherlands: A historical perspective. J. Coast. Conserv. 1998, 4, 109-114. [CrossRef]

6. Roberts, N. Public deliberation in an age of direct citizen participation. Am. Rev. Public Adm. 2004, 34, 315-353. [CrossRef]

7. Kostakopoulou, D. European union citizenship rights and duties. In Routledge Handbook of Global Citizenship Studies; Isin, E., Neyers, P., Eds.; Routledge: London, UK, 2014; pp. 427-436.

8. Larsen, T.A.; Hoffmann, S.; Lüthi, C.; Truffer, B.; Maurer, M. Emerging solutions to the water challenges of an urbanizing world. Science 2016, 352, 928-933. [CrossRef] [PubMed]

9. Brouwer, S.; Büscher, C.; Hessels, L.K. Towards transdisciplinarity: A water research programme in transition. Sci. Public Policy 2017. [CrossRef]

10. Pahl-Wostl, C. Information, public empowerment, and the management of urban watersheds. Environ. Model. Softw. 2005, 20, 457-467. [CrossRef]

11. Wendling, C.; Radisch, J.; Jacobzone, S. The Use of Social Media in Risk and Crisis Communication; OECD: Paris, France, 2013.

12. Stilgoe, J.; Lock, S.J.; Wilsdon, J. Why should we promote public engagement with science? Public Underst. Sci. 2014, 23, 4-15. [CrossRef] [PubMed]

13. Shirk, J.L.; Ballard, H.L.; Wilderman, C.C.; Phillips, T.; Wiggins, A.; Jordan, R.; McCallie, E.; Minarchek, M.; Lewenstein, B.V.; Krasny, M.E. Public participation in scientific research: A framework for deliberate design. Ecol. Soc. 2012, 17, 29-48. [CrossRef] 
14. Gura, T. Citizen science: Amateur experts. Nature 2013, 496, 259-261. [CrossRef] [PubMed]

15. Raddick, M.J.; Bracey, G.; Gay, P.L.; Lintott, C.J.; Cardamone, C.; Murray, P.; Schawinski, K.; Szalay, A.S.; Vandenberg, J. Galaxy zoo: Motivations of citizen scientists. Astron. Educ. Rev. 2013, 12, 1-27.

16. Tulloch, A.I.; Possingham, H.P.; Joseph, L.N.; Szabo, J.; Martin, T.G. Realising the full potential of citizen science monitoring programs. Biol. Conserv. 2013, 165, 128-138. [CrossRef]

17. Thornhill, I.; Loiselle, S.; Lind, K.; Ophof, D. The citizen science opportunity for researchers and agencies. BioScience 2016, 66, 720-721. [CrossRef]

18. Dickinson, J.L.; Shirk, J.; Bonter, D.; Bonney, R.; Crain, R.L.; Martin, J.; Phillips, T.; Purcell, K. The current state of citizen science as a tool for ecological research and public engagement. Front. Ecol. Environ. 2012, 10, 291-297. [CrossRef]

19. McKinley, D.C.; Miller-Rushing, A.J.; Ballard, H.L.; Bonney, R.; Brown, H.; Cook-Patton, S.C.; Evans, D.M.; French, R.A.; Parrish, J.K.; Phillips, T.B. Citizen science can improve conservation science, natural resource management, and environmental protection. Biol. Conserv. 2017, 208, 15-28. [CrossRef]

20. Silva, C.G.; Monteiro, A.; Manahl, C.; Lostal, E.; Holocher-Ertl, T.; Andrade, N.; Brasileiro, F.; Mota, P.G.; Sanz, F.S.; Carrodeguas, J.A. Cell spotting: Educational and motivational outcomes of cell biology citizen science project in the classroom. J. Sci. Commun. 2016, 15, 1-20.

21. Buytaert, W.; Zulkafli, Z.; Grainger, S.; Acosta, L.; Alemie, T.C.; Bastiaensen, J.; De Bièvre, B.; Bhusal, J.; Clark, J.; Dewulf, A. Citizen science in hydrology and water resources: Opportunities for knowledge generation, ecosystem service management, and sustainable development. Front. Earth Sci. 2014, 2, 1-21. [CrossRef]

22. Kullenberg, C.; Kasperowski, D. What is citizen science?-a scientometric meta-analysis. PLoS ONE 2016, 11, e0147152. [CrossRef] [PubMed]

23. Bonney, R. Citizen science: A lab tradition. Living Bird 1996, 15, 7-15.

24. Irwin, A. Citizen Science: A Study of People, Expertise and Sustainable Development; Routledge: London, UK; New York, NY, USA, 1995.

25. Lidskog, R. Scientised citizens and democratised science. Re-assessing the expert-lay divide. J. Risk Res. 2008, 11, 69-86. [CrossRef]

26. Bonney, R.; Ballard, H.; Jordan, R.; McCallie, E.; Phillips, T.; Shirk, J.; Wilderman, C.C. Public Participation in Scientific Research: Defining the Field and Assessing Its Potential for Informal Science Education. A Caise Inquiry Group Report; Center for Advancement of Informal Science Education: Washington, DC, USA, 2009.

27. Schade, S.; Tsinaraki, C. Survey Report: Data Management in Citizen Science Projects; EUR 27920 EN; Publications Office of the European Union: Luxembourg, 2016.

28. Minkman, E.; van der Sanden, M.; Rutten, M. Practitioners' viewpoints on citizen science in water management: A case study in dutch regional water resource management. Hydrol. Earth Syst. Sci. 2017, 21, 153-167. [CrossRef]

29. Jollymore, A.; Haines, M.J.; Satterfield, T.; Johnson, M.S. Citizen science for water quality monitoring: Data implications of citizen perspectives. J. Environ. Man. 2017, 200, 456-467. [CrossRef] [PubMed]

30. Conrad, C.C.; Hilchey, K.G. A review of citizen science and community-based environmental monitoring: Issues and opportunities. Environ. Monit. Assess. 2011, 176, 273-291. [CrossRef] [PubMed]

31. EPA. National Directory of Volunteer Monitoring Programs. Available online: https:/ / yosemite.epa.gov / water/volmon.nsf/Home?OpenForm (accessed on 12 March 2017).

32. Thornton, T.; Leahy, J. Trust in citizen science research: A case study of the groundwater education through water evaluation \& testing program. J. Am. Water Resour. Assoc. 2012, 48, 1032-1040.

33. Little, K.E.; Hayashi, M.; Liang, S. Community-based groundwater monitoring network using a citizen-science approach. Groundwater 2016, 54, 317-324. [CrossRef] [PubMed]

34. Wehn, U.; Rusca, M.; Evers, J.; Lanfranchi, V. Participation in flood risk management and the potential of citizen observatories: A governance analysis. Environ. Sci. Policy 2015, 48, 225-236. [CrossRef]

35. Peckenham, J.M.; Thornton, T.; Peckenham, P. Validation of student generated data for assessment of groundwater quality. J. Sci. Educ. Technol. 2012, 21, 287-294. [CrossRef]

36. Morgan, D.L. Focus Groups as Qualitative Research, 2nd ed.; Sage Publications: Thousand Oaks, CA, USA, 1997.

37. Baptiste, I. Qualitative data analysis: Common phases, strategic differences. Qual. Soc. Res. 2001, $2,22$.

38. Bibby, K. The Pittsburgh Water Microbiome Project. Available online: https://pghwatermicrobiome. wordpress.com/ (accessed on 28 February 2018). 
39. Jennett, C.; Furniss, D.; Iacovides, I.; Wiseman, S.; Gould, S.J.; Cox, A.L. Exploring citizen psych-science and the motivations of errordiary volunteers. Hum. Comput. 2014, 1, 200-218. [CrossRef]

40. Haywood, B.K. Beyond data points and research contributions: The personal meaning and value associated with public participation in scientific research. Int. J. Sci. Educ. Part B 2016, 6, 239-262. [CrossRef]

41. Alender, B.J. Understanding volunteer motivations to participate in citizen science projects: A deeper look at water quality monitoring. J. Sci. Commun. 2016, 15, 1-19.

42. Johnson, M.F.; Hannah, C.; Acton, L.; Popovici, R.; Karanth, K.K.; Weinthal, E. Network environmentalism: Citizen scientists as agents for environmental advocacy. Glob. Environ. Chang. 2014, 29, 235-245. [CrossRef]

43. Van der Kooij, D. Managing regrowth in drinking water distribution systems. In Heterotrophic Plate Counts and Drinking-Water Safety; Bartram, J., Cotruvo, C., Exner, M., Fricker, C., Glasmacher, A., Eds.; IWA Publishing: London, UK, 2003; pp. 199-232.

44. Van der Wielen, P.W.; van der Kooij, D. Effect of water composition, distance and season on the adenosine triphosphate concentration in unchlorinated drinking water in the netherlands. Water Res. 2010, 44, 4860-4867. [CrossRef] [PubMed]

45. Pinto, A.J.; Xi, C.; Raskin, L. Bacterial community structure in the drinking water microbiome is governed by filtration processes. Environ. Sci. Technol. 2012, 46, 8851-8859. [CrossRef] [PubMed]

46. Shaw, J.L.; Monis, P.; Weyrich, L.S.; Sawade, E.; Drikas, M.; Cooper, A.J. Using amplicon sequencing to characterize and monitor bacterial diversity in drinking water distribution systems. Appl. Environ. Microbiol. 2015, 81, 6463-6473. [CrossRef] [PubMed]

47. Bautista-de los Santos, Q.M.; Schroeder, J.L.; Blakemore, O.; Moses, J.; Haffey, M.; Sloan, W.; Pinto, A.J. The impact of sampling, PCR, and sequencing replication on discerning changes in drinking water bacterial community over diurnal time-scales. Water Res. 2016, 90, 216-224. [CrossRef] [PubMed]

48. Van der Kooij, D.; Van Lieverloo, J.H.M.; Schellart, J.; Hiemstra, P. Maintaining quality without a disinfectant residual. J. Am. Water Works Assoc. 1999, 91, 55-64. [CrossRef]

49. Rotman, D.; Hammock, J.; Preece, J.; Hansen, D.; Boston, C.; Bowser, A.; He, Y. Motivations affecting initial and long-term participation in citizen science projects in three countries. In iConference 2014 Proceedings; iSchools: Grandville, MI, USA, 2014; pp. 110-124. [CrossRef]

50. Pedregal, B.; Cabello, V.; Hernández-Mora, N.; Limones, N.; Del Moral, L. Information and knowledge for water governance in the networked society. Water Altern. 2015, 8, 1-19.

51. Bonney, R.; Shirk, J.L.; Phillips, T.B.; Wiggins, A.; Ballard, H.L.; Miller-Rushing, A.J.; Parrish, J.K. Next steps for citizen science. Science 2014, 343, 1436-1437. [CrossRef] [PubMed]

52. EC. Responsible Research \& Innovation; European Commission. Available online: https:/ / ec.europa.eu/ programmes/horizon2020/en/h2020-section/responsible-research-innovation (accessed on 21 March 2017).

53. European Union (EU). Rome Declaration on Responsible Research and Innovation in Europe; EU: Brussels, Belgium, 2014.

54. Silvertown, J. A new dawn for citizen science. Trends Ecol. Evol. 2009, 24, 467-471. [CrossRef] [PubMed]

(C) 2018 by the authors. Licensee MDPI, Basel, Switzerland. This article is an open access article distributed under the terms and conditions of the Creative Commons Attribution (CC BY) license (http:/ / creativecommons.org/licenses/by/4.0/). 